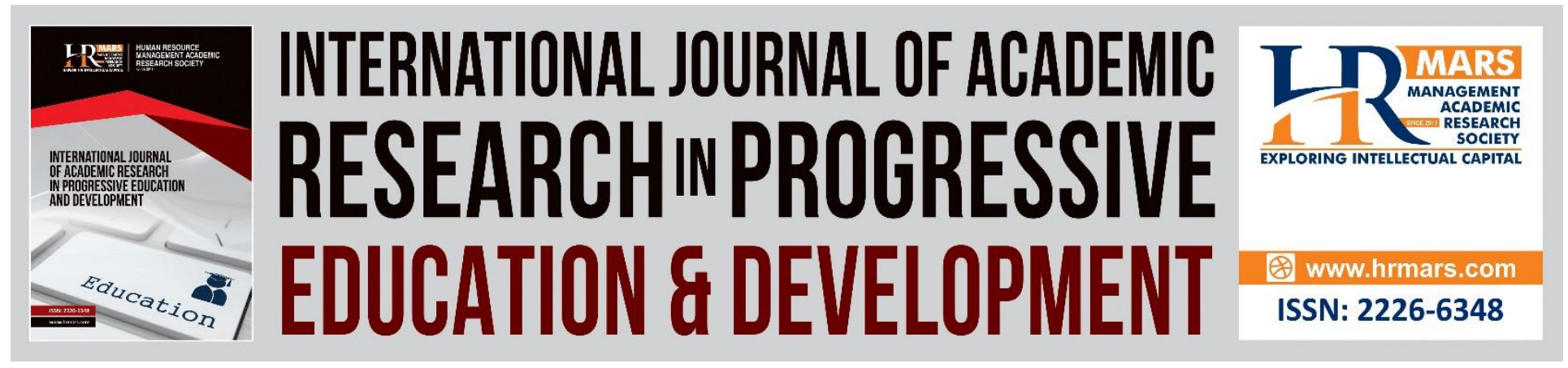

\title{
The Effect of Interactive Whiteboard in Phonemic Segmentation on Word Recognition among Beginning Readers
}

\section{Vanesri Kasi, Noor Aini Ahmad}

To Link this Article: http://dx.doi.org/10.6007/IJARPED/v10-i1/9044 DOI:10.6007/IJARPED/v10-i1/9044

Received: 11 December 2020, Revised: 14 January 2021, Accepted: 31 January 2021

Published Online: 18 February 2021

In-Text Citation: (Kasi \& Ahmad, 2021)

To Cite this Article: Kasi, V., \& Ahmad, N. A. (2021). The Effect of Interactive Whiteboard in Phonemic Segmentation on Word Recognition among Beginning Readers. International Journal of Academic Research in Progressive Education and Development, 10(1), 370-376.

Copyright: (C) 2021 The Author(s)

Published by Human Resource Management Academic Research Society (www.hrmars.com)

This article is published under the Creative Commons Attribution (CC BY 4.0) license. Anyone may reproduce, distribute, translate and create derivative works of this article (for both commercial and non-commercial purposes), subject to full attribution to the original publication and authors. The full terms of this license may be seen

at: $\underline{\text { http://creativecommons.org/licences/by/4.0/legalcode }}$

Vol. 10(1) 2021, Pg. 370 - 376

Full Terms \& Conditions of access and use can be found at http://hrmars.com/index.php/pages/detail/publication-ethics 


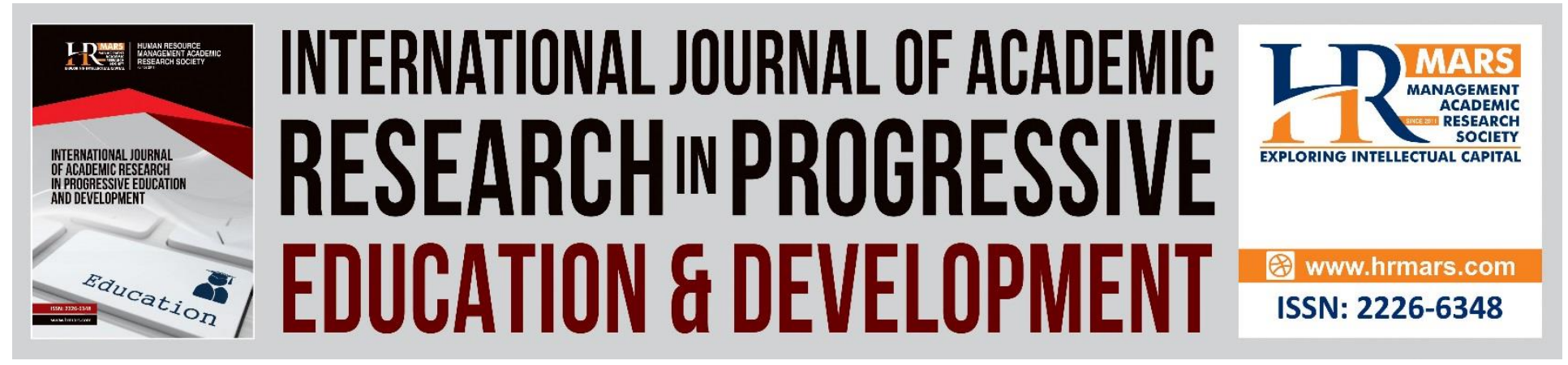

\title{
The Effect of Interactive Whiteboard in Phonemic Segmentation on Word Recognition among Beginning Readers
}

\author{
Vanesri Kasi, Noor Aini Ahmad \\ Department of Special Education, Faculty of Human Development, Universiti Pendidikan Sultan \\ Idris, 35900 Tanjong Malim, Perak, Malaysia.
}

\begin{abstract}
Developing effective reading skills is essential among primary learners of English given that this will create many types of awareness, in particular, phonemic awareness. Studies have revealed that there is a weak performance in the skill of reading among primary school students and beginning readers word-reading ability.This study investigated the effect of phonemic segmentation skill on word recognition among beginning readers by using interactive whiteboard. The instruments used were word recognition test and cross-sectional questionnaire. The independent sample paired t-test, dependent t-test, descriptive statistics, and one way ANOVA were employed to analyze the data. The pre-tests and post-tests of word recognition were administered to 41 beginning readers in the experimental and control groups. The experimental group received the treatment using interactive whiteboard, whereas the control group was taught using the chalkboard. Meanwhile, the questionnaires were distributed to 86 teachers. The findings showed a significant difference in word recognition test scores between the experimental and control groups. The findings revealed that the teachers provided positive support towards using phonemic segmentation and interactive whiteboard.

Keywords: Phonemic Awareness, Reading Skills, Beginning Readers, Interactive Whiteboard, Word Recognition.

\section{Introduction}

Reading is a vital skill that influences children's educational aspect in life. Recent research has proved that developing strong reading skills forms a critical cornerstone in the life of children in their beginning years of schools and leads to good academic outcomes (Senechal \& LeFevre, 2002). Research has also found that reading in English language is a complicated system of skills and knowledge in which all parts of that system work together and enhance one another (Senechal \& LeFevre, 2002; Adams, 1994). Thus, the children need more opportunities in academic success and most of the time it closely related with having a well prepared teachers
\end{abstract}


who understand their strengths and welcome individual limitations they bring along to the classroom (Ahmad \& Khoo, 2020).

Three considerable skills that will be addressed in this study work together within the process of learning to read in order to have better readers. These skills encompass phonemic awareness, word recognition (International Reading Association, 1999) and integrating interactive whiteboard as an instructional tool of technology (Ishtaiwa \& Shana, 2011).

The first skill, phonemic awareness, refers to the ability to hear and manipulate the sounds in words and the ability to understand that these oral words and their syllables are made up of a series of sounds (Yopp, 2009). Phonemic awareness falls under the umbrella of phonological awareness. Phonological awareness is a component of metalinguistic awareness which is the process of thinking about one's own language. It involves segmenting spoken words into phonemes (Chapman, 2003). The second skill is the word recognition. This skill can be defined as words that are automatically and immediately recognized as a whole by beginning readers (Ehri, 2014). Lastly, the third skill, which is the incorporation of the interactive whiteboard (IWB), is a pedagogical tool in a form of a large touch-sensitive board which is linked to a computer and a digital projector. The image from the screen of the computer can be shown on the large board (Smith et al., 2005). The technology functions by enhancing one's current perception of reality. By contrast, virtual reality replaces the real world with a simulated scene (Ahmad, 2020). It is essential to note that the use of technology can be integrated in classrooms.

Ishtaiwa and Shana (2011) stressed that the use of technology has a pivotal role in teaching and learning a large number of subjects, including languages. It is used as an instructional tool as well. Researchers consider being eminently interactive tools presented to both teachers and students who can manipulate and control programs (Khoo, Ahmad \& Ismail, (2020). These particular programs are engaged by a touch sensitive screen. It is important to note that the IWB, phonemic awareness, specifically phonemic segmentation, and word recognition will have a considerable focus in this study in relation to the educational context (Yunus, Hasliza \& Ahmad, 2019). Thus, the interactive whiteboard (IWB) is considered one kind of technology that can be incorporated into the reading classroom.

\section{Conceptual Frame work}

Phonemic awareness, phonemic segmentation in particular, has been identified by researchers as an important link and powerful predictor of the development of reading skill at early stages (Hammer \& Miccio, 2006). A visual representation of the framework was provided in Figure 1. Information concerning reading was initially provided. The selection criteria used to identify potential participants required that teachers participants (Ahmad \& May, 2018). After that, the links established between reading and phonemic awareness, reading and word recognition, and finally reading and the interactive whiteboard were reviewed. 


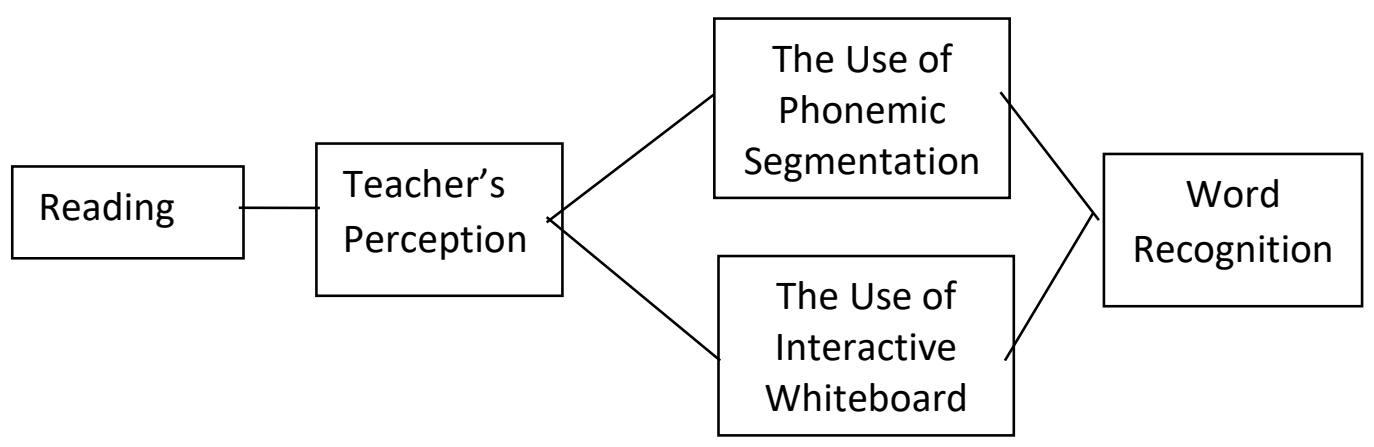

Figure 1. The Conceptual Framework.

\section{Research Design}

The research began with a quasi-experimental design. This particular design was conducted to investigate the effect of the use of the interactive whiteboard in teaching phonemic segmentation skill on beginning readers' word recognition. Two classes of the participant teacher represented the two intact groups. Group A, the experimental group, received phonemic segmentation instructions using the interactive whiteboard. On the other hand, group $B$, the control group, received phonemic segmentation instructions without the use of the interactive whiteboard. Both groups had a pre-test and post-test. Table 1 explains the experimental design for this study.

Table 1. Research Experimental Design

\begin{tabular}{llll}
\hline GROUP & INITIAL & EXPERIMENTAL & FINAL \\
& ASSESSMENT & ACTIVITY & ASSESSMENT \\
\hline EXPERIMENTAL & Pre-test & Activities in phonemic & Post-test \\
GROUP & & segmentation skill using & \\
& & the IWB & \\
CONTROL & Pre-test & Activities in phonemic & Post-test \\
GROUP & & segmentation skill using & \\
& & traditional chalkboard &
\end{tabular}

(Adapted from Campregher, 2010)

After the post-test period in the quasi- experimental design, a cross-sectional questionnaire was conducted and distributed to teachers of beginning readers. This questionnaire addressed the perceptions of beginning readers teachers towards the use of phonemic segmentation skill in improving word recognition as well as their perceptions towards the use of the interactive whiteboard in improving word recognition among beginning readers. The next chapter demonstrates the variables of the study. 
INTERNATIONAL JOURNAL OF ACADEMIC RESEARCH IN PROGRESSIVE EDUCATION AND

DEVELOPMENT

Vol. 10, No. 1, 2021, E-ISSN: $2226-6348$ @ 2021 HRMARS

\section{Finding and Discussion}

Table 2. shows the group statistics of the word recognition pre-test for the experimental and control groups administered for beginning reader. It also shows the number of participants, mean and standard deviation on the word recognition pre-test for each of these two groups.

Table 2. Standard deviation and Mean Results of Pre- Word Recognition Tests of the Two Groups

\begin{tabular}{lllll}
\hline Group & $\mathbf{N}$ & Mean & SD & Std. Error Mean \\
\hline Experimental & 21 & 2.90 & 2.52 & .55 \\
Control & 20 & 1.55 & 2.06 & .46 \\
\hline
\end{tabular}

The results of the Pre- Word Recognition Tests administered for the beginning reader in both groups are shown in Table 3. below. The results showed that there was no significant difference between the two groups in the word recognition tests ( $t=1.87, p>.068$ ). This means that the abilities of the word recognition tests of the experimental group and the control group were assumed to be identical at the beginning of the study. Therefore, any significant differences to detected after the treatment will be attributed to the effect of the IWB.

Table 3. Independent Sample T-Test Results of the Two Groups

\begin{tabular}{lccccc}
\hline Group & $\mathbf{N}$ & Mean & SD & t & P \\
\hline Experimental & 21 & 2.90 & 2.52 & & \\
Control & 20 & 1.55 & 2.06 & 1.87 & .068 \\
\hline
\end{tabular}

Based on Table 4, the results indicated that there was significant difference between the experimental and the control groups in the post word recognition test $(t=2.58, p<.05)$. The mean score of the experimental group was better than the control group. The use of interactive whiteboard that has resulted in the improvements of the experimental group students regarding the word recognition test was positively confirmed. The Interactive whiteboard therefore efficiently helped in improving students' skills in the phonemic segmentation skill.

Table 4. Independent Sample T-Test Results of Post Word Recognition Tests of the Two Groups

\begin{tabular}{llllll}
\hline Control & $\mathbf{N}$ & Mean & SD & $\mathbf{T}$ & $\mathbf{p}$ \\
\hline Pre-test & 20 & 1.55 & 2.06 & -3.68 & .002 \\
& & & & & \\
Post-test & 20 & 3.00 & 3.00 & & \\
\hline
\end{tabular}


Vol. 10, No. 1, 2021, E-ISSN: 2226-6348 @ 2021 HRMARS

Table 5. illustrated the paired-t test results. It showed that the treatment made a significant difference on the experimental group when using the interactive whiteboard $(t=-5.26, p$ $<$.05). Though the mean score of the experimental group is still relatively low, it nonetheless indicates a noticeable development in the group's word recognition. This becomes clearer when we compare the experimental group results in both pre and post word recognition tests based on Table 1.5 below.

Table 5. Paired Sample T-Test Results of Pre- and Post-Word Recognition Tests of the Experimental Group

\begin{tabular}{lccccc}
\hline Group & $\mathbf{N}$ & Mean & SD & t & p \\
\hline Experimental & 21 & 6.24 & 4.76 & & .014 \\
Control & 20 & 3.00 & 3.00 & & \\
\hline
\end{tabular}

From table 6, it is obvious that the control group has made little advancement in both pre-and post-word recognition tests since the mean score of the control group is low. According to table 1.6 below, there is significant difference in word recognition ability $(\mathrm{t}=$ 3.68, $P=0.002$ ); i.e. $p<.05$. However, the progress could be attributed to the instruction in phonemic segmentation skill.

Table 6. Paired Sample T-Test Results of Pre- and Post-Word Recognition Tests of the Control Group

\begin{tabular}{llllll}
\hline Experimental & $\mathbf{N}$ & Mean & SD & $\mathbf{T}$ & $\mathbf{P}$ \\
\hline Pre-test & 21 & 2.90 & 2.52 & -5.26 & .000 \\
Post-test & 21 & 6.24 & 4.76 & & \\
\hline
\end{tabular}

\section{Conclusion}

Concerning the cross-sectional questionnaire, the findings revealed that teachers support favorable uses towards improving beginning reader's word recognition in relation to phonemic segmentation skill as well as the incorporation of the interactive whiteboard. Moreover, it is important to note that demographic factors such as gender, age, years of experience and academic degree have been examined to find out any significant differences that may affect the teachers' responses. Thus, there were no significant differences in the teachers' perceptions towards the use of phonemic segmentation skill as well as the interactive whiteboard in relation to gender, years of experience, Academic degree, and age.

\section{Corresponding Author}

Noor Aini Ahmad

Department of Special Education, Faculty of Human Development, Universiti Pendidikan Sultan Idris, 35900 Tanjong Malim, Perak, Malaysia. 
INTERNATIONAL JOURNAL OF ACADEMIC RESEARCH IN PROGRESSIVE EDUCATION AND

DEVELOPMENT

Vol. 10, No. 1, 2021, E-ISSN: 2226-6348 @ 2021 HRMARS

\section{References}

Adams, M. J. (1994). Beginning to read: Thinking and learning about print. Cambridge, MA: MIT Press.

Ahmad, N.A. (2020). Engaging and Facilitating Language Skills Using Augmented Reality as A Medium of Learning and Teaching. 6. 133-138.

Ahmad, N. A., \& May, Y. S. (2018). Challenges in Preparing Teachers for Inclusive Education and Its Impact to Students with Learning Disabilities. International Journal of Academic Research in Progressive Education and Development, 7(3), 569-581.

Ahmad, N. A., \& Khoo. (2020). Need Analysis on Improving Reading Skills Using Interactive Kit Media Among Low Achievers. International Journal of Psychosocial Rehabilitation. 24. 7432-7438. 10.37200/IJPR/V24I7/PR270711.

Chapman, M. L. (2003). Phonemic awareness: Clarifying what we know. Literacy Teaching and Learning, 7(1 \& 2), 91-114.

Ehri, L. C. (2014) Orthographic mapping in the acquisition of sight word reading, spelling memory, and vocabulary learning. Scientific Studies of Reading, 18(1), 5-21.

Hammer, C. S., \& Miccio, A. W. (2006). Early language and reading development of bilingual preschoolers from low-income families. Topics in Language Disorders, 26(4), 322-337.

International Reading Association. (1999). Using multiple methods of beginning reading instruction: A position statement of the International Reading Association. Newark, Delaware.

Ishtaiwa, F. F., \& Shana, Z. (2011). The use of interactive whiteboard (IWB) by pre-service teachers to enhance Arabic language teaching and learning. Learning and Teaching in Higher Education: Gulf Perspectives, 8(2), 1-18.

Senechal, M., \& LeFevre, J. (2002). Parental involvement in the development of children 's reading skills: A five year longitudinal study. Child Development, 73(2), 445-460.

Smith, H. J., Higgins, S., Wall, K., \& Miller, J. (2005). Interactive whiteboards: Boon or bandwagon? A critical review of the literature. Journal of Computer Assisted Learning, 21(2), 91-101.

Yopp, H. K., \& Yopp, R. H. (2009). Phonological awareness is child's play! YC Young Children, 64(1), 12-21. 